\title{
LARS-OLOF ÅHLBERG, NOTIONS OF THE AESTHETIC AND OF AESTHETICS: ESSAYS ON ART, AESTHETICS, AND CULTURE
}

(Frankfurt am Main: Peter Lang, 2014), 427 pages.

\section{Arto Haapala}

In his recent book, Notions of the Aesthetic and of Aesthetics: Essays on Art, Aesthetics, and Culture, ${ }^{1}$ the former chairman of the Nordic Society of Aesthetics and Professor Emeritus of Aesthetics at the University of Uppsala, Lars-Olof Åhlberg, has put together a collection of essays discussing a variety of topics in philosophical aesthetics and cultural theory. The earliest essays go back to the early 90's, with the last originating from 2008. Åhlberg has divided the essays under four headings: "Art and Aesthetics," "Music, Literature, and Painting," "Heidegger and the Essence of Art," and "Modernity/Postmodernity and Culture." The terrain covered is wide: from historical to contemporary topics, from constructive to critical analysis. The volume also presents a set of illustrative photos of the paintings discussed in the essays.

One can fully agree with Åhlberg's own statement about the essays: "My approach to aesthetics and the philosophy of art has not changed much over the years...” (p. 9). It is clear that all the essays are argumentative analyses, at least to a certain extent, aiming at conceptual clarity. In this sense it is safe to say that Åhlberg works within the Anglo-American "analytic" tradition, though he does make references to continental writers as well.

The first essay, "The Nature and Limits of Analytic Aesthetics" discusses different conceptions of analytic aesthetics, and one of Åhlberg's cautious conclusions is that "Whatever analytic aesthetics is, it is analysis of some kind, and the purpose of analysis is to achieve clarity" (p. 25). But unlike so many analytic aestheticians, Åhlberg himself deepens his analyses with historical references. Indeed, in the Introduction he acknowledges the importance of history: "In recent years I have become increasingly interested in the history of aesthetics and in the historicity of the fundamental
Lars-Olof Ahlberg

Notions of the Aesthetic and of Aesthetics

Essays on Art, Aesthetics, and Culture

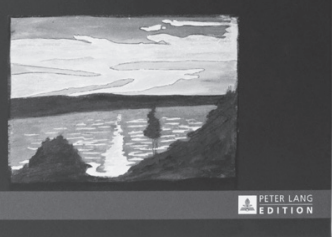


concepts in aesthetics" (p. 9). The second essay, "The Invention of Modern Aesthetics: From Leibniz to Kant," is a fine example of Åhlberg's historical interests - an illuminating account of the early phases of philosophical aesthetics, for which, it is worth noting, Åhlberg relies primarily on primary sources.

In the title essay, "Notions of the Aesthetic and of Aesthetics," Åhlberg's conceptual analysis is again firmly based on historical references. The distinctions Åhlberg makes between different usages of "aesthetic" and "aesthetics" are useful and the conclusions commonsensical, although by no means widely accepted within philosophical aesthetics. Åhlberg also formulates his ideas elegantly and in an appealing way: "Understanding various uses of 'aesthetics' and 'aesthetic' presupposes, I believe, contextual sensitivity and a historical perspective. Understanding various language uses is important, but understanding the motivations behind various conceptions of the aesthetic and of aesthetics is even more important, since it may improve our judgments on matters aesthetic and our dealings with art and the aesthetic” (p. 73). I could not agree with this more.

The essays "Aesthetics, Philosophy of Culture, and the 'Aesthetic Turn"” and "The Distinction Between Aesthetics and the Sociology of Art: Remarks on Bourdieu's Critique of Aesthetics” continue to tackle the same issues concerning the limits and nature of philosophical aesthetics. In the former, Åhlberg pays special attention to Richard Shusterman's and Wolfgang Welsch's view, and he is critical of the attempt to broaden the field of aesthetics in the ways Shusterman and Welsch have suggested: "There is nothing wrong in studying the aestheticization of ethics and everyday life. On the contrary, it is important to study the manifold of aestheticization processes at work in contemporary culture, but I doubt whether these concerns should be at the centre of philosophical aesthetics. The arts and the experience of art raise many important and intriguing problems that should not be put into a mixed and rather ill-defined bag of 'transaesthetics', nor should they be swallowed by a new 'somaesthetics'” (p. 96).

I am not convinced that Welsch's or Shusterman's aim has been to ignore (p. 97) traditional issues in the philosophy of art or even try to dilute them by introducing concepts such as "transaesthetics" or "somaesthetics." Shusterman's project, at least, has been to broaden the scope of philosophical aesthetics. The same goes for those - such as myself - interested in the issues of everyday aesthetics. Why shouldn't philosophical aesthetics look at aesthetic properties and issues in our everyday lives? This does not mean "the aestheticization of everything” (p. 97), as Åhlberg 
claims. This I find the weakest point in Åhlberg's views: being too conservative about the limits of philosophical aesthetics.

In "Understanding and Appreciating Art: The Relevance of Experience,” Åhlberg argues persuasively for the relevance of artists' intentions in interpreting and understanding their works. $\mathrm{He}$ operates with a wide notion of intention, quoting Wittgenstein, who writes in Philosophical Investigations: "(a)n intention is embedded in its situation, in human customs and institutions” (p. 114). Understanding artists' intentions does not require a peep into their heads, so to speak, but taking the relevant context into account.

Åhlberg's analyses of different art forms are illuminating. He discusses, among other things, problems of formalism in music, Susanne Langer's theory of representation and emotion in music, expression in art, and value in literature. Even though some of the essays go back to the early 90's, they are not outdated such that they would not deserve a reading now, a quarter of a century later. Obviously lots and lots have been written about these issues in the past decades, and Åhlberg's references are not always up-to-date, but his treatments are still useful, and the way he puts forward his ideas is appealing.

Perhaps the most surprising section in the book is the one on Martin Heidegger's ideas about art. Åhlberg seems to have some kind of love-hate relationship with Heidegger. He discusses Heidegger's The Origin of the Work of Art in great detail, and comments and criticizes numerous Heidegger scholars. The outcome, after tens of pages, is rather devastating: "It is difficult to see that Heidegger's essay and his reflections on the 'essence' of art are of any relevance for contemporary philosophy of art and contemporary art. There are too many inconsistencies and obscurities in his text" (p. 312). And further: "Heidegger's Great Art has little to do with visual, verbal and aural arts as we encounter them in contemporary artworlds. He is, or rather was, to a large extent out of touch with the realities of the visual arts, did not show any interest in narrative literature, which is literally a form of world-creating, and he was, moreover, out of tune when it comes to music" (pp. 313-314).

This might all be true, but one wonders why anybody would take so much time and effort just to try to demonstrate that there is no point in reading Heidegger. Clearly, Åhlberg has read his Heidegger, and even though some of his critical points might not do justice to the more liberal Heidegger scholar such as Hubert Dreyfus, the two Heidegger-essays are a good reminder about the dangers of an uncritical reading of Heidegger - or of any other classical thinker. 
The last section of the book extends Åhlberg's considerations beyond philosophical aesthetics. Åhlberg discusses problems in the philosophy of history, Lyotard's concept of the sublime, the challenges of evolutionary psychology to philosophy and to our understanding of humans. The last essay, "Scientism, Humanism, and the Humanities: The Challenge of Evolutionary Psychology," gives a very topical analysis on the limits of evolutionary explanations. Again, I completely agree with Åhlberg's position giving a role to both evolutionary and cultural explanations, emphasizing that evolutionary explanations are not enough to understand what humans are: "Whatever else human beings are, they are 'self-interpreting animals', as Charles Taylor has put it, which implies, among other things that there is no unmediated and naked view of reality as such, no grasp of reality which is not culturally and linguistically informed" (p. 394).

This is a very fine collection of essays - well informed, sophisticated, and elegantly argued. Åhlberg avoids many of the sins of the Anglo-American tradition by taking into account the historical foundation of philosophical problems. And unlike so many British and American writers Åhlberg refers to a number of non-native English speakers, and to less-known sources within the Englishspeaking academia. This gives an aura of freshness to many of his essays.

All in all, Åhlberg's essays deserve a wide readership - they give food for thought for both professional philosophers and students, as well as anyone else interested in theoretical issues in the arts. They are also a good example of the vividness of philosophical aesthetics within the Nordic countries - a link in a chain which will hopefully only get stronger in the years to come.

1. All the following page references to the book appear in parentheses. 